\title{
Developmental function of Elf-1: an essential transcription factor during embryogenesis in Drosophila
}

\author{
Sarah J. Bray ${ }^{1,2}$ and Fotis C. Kafatos \\ The Biological Laboratories, Harvard University, Cambridge, Massachusetts 02138 USA
}

The Drosophila transcription factor Elf-1 binds to a cis-acting element that is essential for neuronal expression of the Dopa decarboxylase gene $(D d c)$. Elf-1 also stimulates transcription from the $D d c$ and Ultrabithorax promoters in vitro. To investigate the function of this factor in vivo we have screened for mutations and identified the Elf-1 gene as grainyhead (grh), a previously known embryonic lethal locus. Elf-1/grh mutations cause late embryonic lethality accompanied by multiple defects in the cuticle and head skeleton. Using $D d c-l a c Z$ gene fusions, we show that these mutations affect $D d c$ expression in the embryo. Surprisingly, however, epidermal expression is disrupted, whereas neuronal expression remains unaffected. Analysis of the mutant phenotype indicates that Elf-1 coordinately regulates multiple genes involved in the differentiation of epidermal structures. The results highlight the importance of genetic analysis in the study of proteins required for developmental regulation of gene expression.

[Key Words: Drosophila development; epidermal/neural differentiation; transcription factor; Ddc; Ubx]

Received May 15, 1991; revised version accepted July 1, 1991.

Differential gene expression is a key facet of the generation of cell diversity during development. Considerable progress has been made toward understanding how the early specification of the Drosophila body plan is brought about through a hierachy of transcription factors (see Akam 1987; Scott and Carroll 1987; Ingham 1988). However, little is known about the molecules that act subsequently to bring about the differentiation of the appropriate morphological structures. We have been studying a process that occurs late in the differentiation pathway, namely the expression of the Drosophila Dopa decarboxylase gene $(D d c)$. Identifying the protein factors required for correct expression of this gene will provide a model for tissue-specific gene expression and will help in elucidating the pathway between the early-acting pattern formation genes and the final differentiated state of the organism.

$D d c$ is expressed in at least two tissues at the end of embryogenesis, the nervous system and the epidermis (Wright et al. 1976; Livingstone and Tempel 1983; Valles and White 1986; Wright 1987). In the former, the enzyme is required for the synthesis of the neurotransmitters serotonin and dopamine, and in the latter it is needed for hardening and coloring the cuticular structures. Expression of $D d c$ in the two tissues involves at least partially separate regulation, since deletion and point mutations

${ }^{1}$ Corresponding author.

${ }^{2}$ Present address: Department of Anatomy, University of Cambridge, Cambridge, CB2 3DY England. in this gene have been identified that specifically affect its expression in one or the other tissue (Scholnick et al. 1986; Bray et al. 1988, 1989; Johnson et al. 1989/. For example, altering $2 \mathrm{bp}$ in the cis-acting element I sequence $(-72$ to -57 bp upstream of $D d c$ transcription start) leads to a gene that can be expressed in epidermal cells but not in the nervous system when reintroduced into the germ line by P-element transformation. This sequence therefore shows the characteristics of a central nervous system (CNS)-specific cis-acting element.

A protein has been purified that binds to element $I$ in a manner affected by the mutations that abolish neuronal expression (Bray et al. 1989). These results suggest that the binding factor Elf-1 may mediate the CNS-specific expression of $D d c$ through interaction with element I. Separate in vitro studies on the purifed protein (also called NTF-1; Biggin and Tjian 1988; Dynlacht et al. 1989) have shown that it can stimulate transcription from the $D d c$ promoter and from the promoters of the Ultrabithorax $(U b x)$ and fushi tarazu (ftz) genes. Moreover, an Elf-1-binding site has been detected in the engrailed (en) gene (Soeller et al. 1988). Both element I and the related sequence in en are highly conserved in diverged Drosophila species, suggesting a fundamental role in the regulation of these genes (Bray and Hirsh 1986; Kassis et al. 1989).

The observed interactions of Elf- 1 with both $D d c$ and the three other genes appear anomalous in some respects. $D d c$ is expressed late in development and might be viewed as an end product because the enzyme it en- 
codes catalyzes the formation of molecules that are characteristic of the fully differentiated cell. $U b x, f t z$, and en act early during embryogenesis and are involved in patterning of embryonic structures. Furthermore, the expression pattern of Elf-1 in the nervous system is not fully consonant with its proposed role as a $D d c$ regulator (Bray et al. 1989). We therefore wanted to investigate the role of Elf-1 during development. If the aim is to understand the mechanisms of tissue-specific gene expression, it is essential to discover how the absence or alteration of a transcription factor affects development and specifically how it affects in vivo expression of the genes to which it binds in vitro. We have taken a genetic approach to this problem and report the isolation of Elf- 1 mutations and describe their effects on embryonic development and on expression of $D d c, U b x, f t z$, and en.

\section{Results}

\section{Identification of Elf-1 mutations}

The gene encoding Elf- 1 maps to position $54 \mathrm{~F}$ on the second chromosome in Drosophila (Bray et al. 1989; Dynlacht et al. 1989). Two chromosomal deficiencies that remove sequences in this region have been isolated: $D f(2 R) P c l^{7 B}$ extending from $54 \mathrm{E} 8$ to $55 \mathrm{Cl}$ and $D f(2 R) P c l^{11 B}$ removing 54F6-55Cl-3 (Duncan 1982). Using anti-Elf-1 antibodies, we tested whether these deficiencies, which we refer to as $D f 7$ and $D f 11$, respectively, remove the Elf- 1 gene. Nuclear Elf- 1 protein can clearly be detected in $D f 11$ embryos but is absent from $D f 7$ embryos (Fig. 1). In both instances the homozygous deficiency embryos can be easily distinguished as they are pooriy differentiated and smaller than wild type. As $D f 11$ does not remove the gene encoding Elf- 1 , but $D f 7$ removes part or all of it, we were able to use these two overlapping deficiencies to isolate mutations in a very small interval of the chromosome. We used an F2 lethal screen (see Materials and methods) on the basis of the assumption that Elf- 1 is an essential protein so that mutations would be lethal in combination with $D f 7$. All mutations that were lethal in trans to $D f 7$ were then tested with $D f 11$ to identify alleles that survived in combination with the latter deficiency.

From a screen of 3260 chromosomes, 13 were identified that satisfied these criteria. Inter se complementation analysis permitted assignment of the mutations to four complementation groups (one to four alleles per group). These groups were assayed for aberrations in the Elf-1 gene by using antibodies to screen for mutations that affected expression of the Elf-1 antigen. To make identification of the $1 / 4$ of the progeny that were homozygous mutant possible, we used a balancer chromosome marked with a transposon expressing the $\beta$-galactosidase gene. The progeny were analyzed for Elf- 1 and $\beta$-galactosidase expression in double label experiments. All four alleles of one complementation group (B28, B32, B35, and B37) showed altered Elf-1 expression in homozygotes (i.e., the class of embryos that lacked $\beta$-galactosidase; Fig. 2). In three of these no Elf-1 protein was
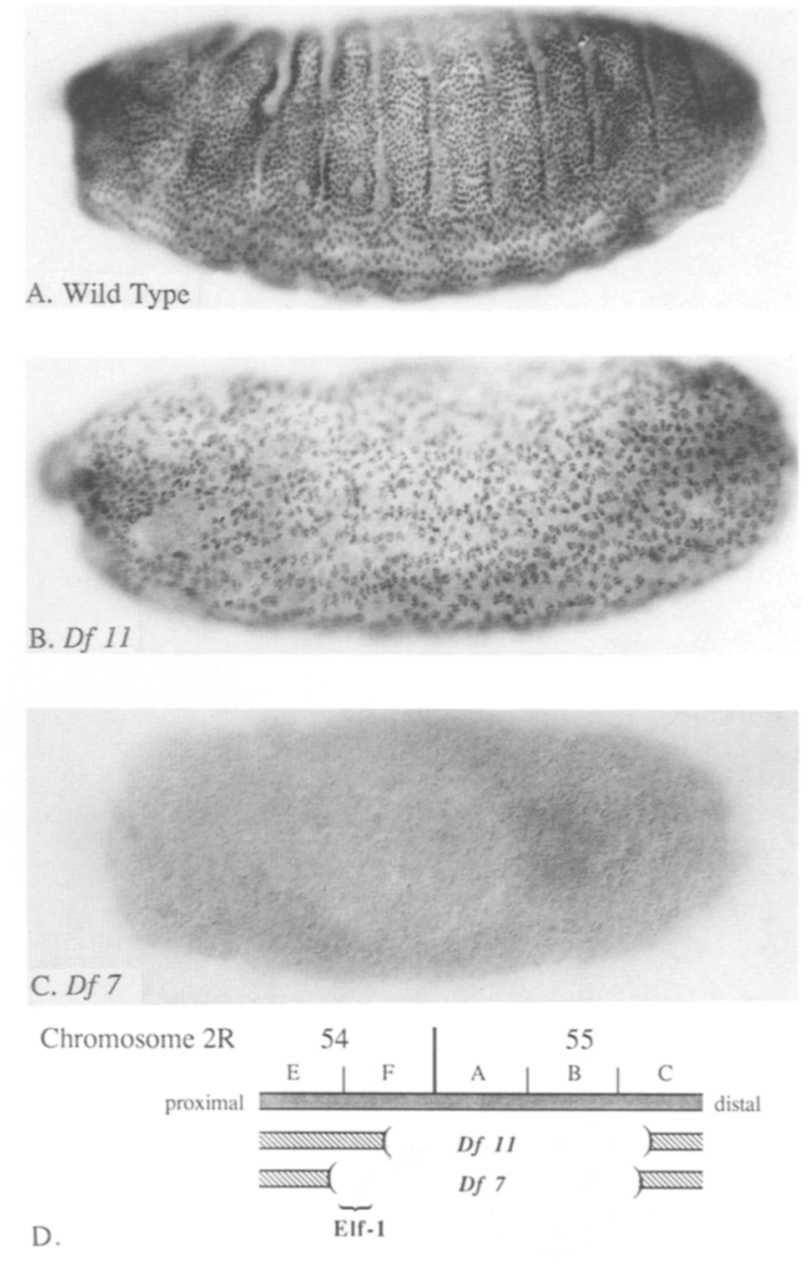

Figure 1. Elf-1 is not present in $D f 7$ embryos. Elf-1 expression was visualized in wild-type $(A), D f 11(B)$, and $D f 7(C)$ embryos with an anti-Elf- 1 monoclonal antibody and a horseradish peroxidase-conjugated anti-mouse secondary antibody. A graphic map of the deficiencies is represented $(D)$. Nuclear staining is visible in wild-type and $D f 11$ embryos but not in $D f 7$ embryos. Embryos were collected and aged in parallel and are all at approximately stage 14 (Campos-Ortega and Hartenstein 1985) of embryonic development. The homozygous deficiency embryos were identified on the basis of their poorly differentiated phenotype. In all embryos, anterior is to the left; the plain of focus is on the ventrolateral epidermis in $A$ and $B$ and on the ventral epidermis in $C$.

detectable and in the fourth (B28) Elf-1 was absent from the epidermis but not from the nervous system.

To confirm that the alleles correspond to mutations within the Elf-1 gene it would be desirable to show by transformation that Elf-1 DNA rescues the mutations. We have not attempted these experiments because preliminary mapping of the Elf- 1 gene shows that it is large, spanning at least $30 \mathrm{~kb}$ (S.J. Bray, unpubl.), which makes transformation problematic. Instead, we characterized the lesion of one allele at the molecular level. Gradient denaturing gel electrophoresis was used to identify gene fragments that had altered base composition compared 
Figure 2. Mutations eliminate Elf-1 expression. Embryos were incubated with anti-Elf-1 monoclonal antibodies visualized with an FITC-conjugated secondary antibody $(A, C)$ and anti- $\beta$-galactosidase antibodies visualized with a rhodamineconjugated secondary antibody $(B, D)$. In the first embryo $(A, B)$, Elf- 1 is detected in the nuclei of all epidermal cells $(A)$ and $\beta$-galactosidase is detected in select cells, principally in the nervous system $(B)$. The second embryo is a mutant as revealed by the absence of $\beta$-galactosidase $(D)$ and has no detectable Elf-1 $(C)$. Embryos are progeny from the cross */CyO-lacZ $\times D f 7 /$ $C y O-l a c Z$, where * represents the mutagenized chromosome and $\mathrm{CyO}-\mathrm{lacZ}$ is a $\mathrm{CyO}$ balancer chromosome carrying a P-element insertion bearing lacZ. $\beta$-Galactosidase therefore identifies three of four of the progeny $1 * / C y O-l a c Z, D f 7 / C y O-$ $l a c Z$, and $C y O-l a c Z / C y O-l a c Z$, as repre-

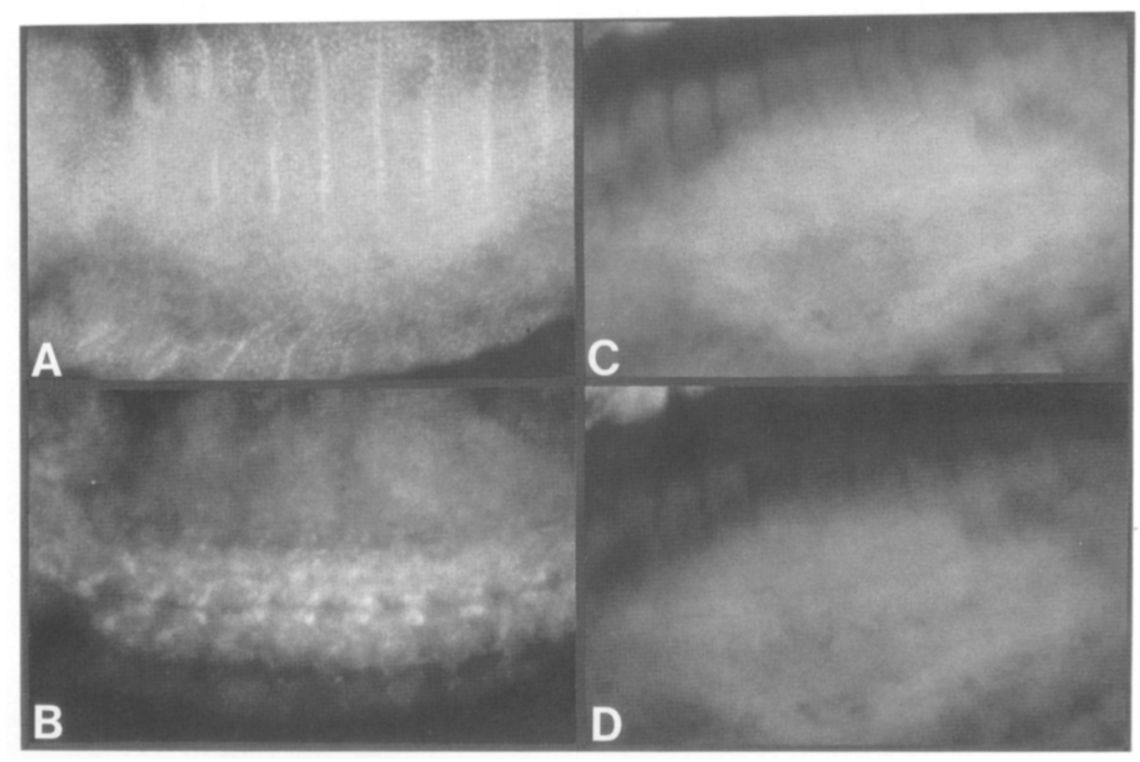
sented in $B$ and is not detectable in the */Df7 mutant embryos $(D)$. The allele shown is $B 37$. In the original test for Elf- 1 mutants the different alleles were scored blind. The embryos are stage 14; anterior is to the left and dorsal is up.

to the parental chromosome (Curtis et al. 1989; Gray et al. 1991). Altered fragments were identified in two of the four alleles (B32 and B37; data not shown), and one of these, B37, was cloned from homozygous mutant embryos using polymerase chain reaction (PCR) to amplify the appropriate fragment. The DNA sequence of the altered fragment revealed a deletion of $7 \mathrm{bp}$ from the Elf1-coding sequence leading to a frameshift and thus to a truncated protein (Fig. 3A). In vitro studies with truncated Elf- 1 proteins demonstrate that truncations in the vicinity of the mutation interfere with the ability of the protein to bind DNA (Fig. $3 \mathrm{~B}$ ) even when not removing the DNA-binding domain per se (data not shown). The B37 mutation occurs in a common exon downstream of the sites of alternative splicing in Elf- 1 and thus affects all forms of the protein.

\section{Phenotype of Elf-1 mutants}

The four Elf- 1 alleles are all embryonic lethal. The most severe alleles, B32 and B37, show a similar phenotype when homozygous and in combination with $D f 7$, sug. gesting that they lead to complete or near-complete inactivation of the protein. The embryos, which die at the end of embryogenesis, have apparently normal segmentation but have altered head skeleton and cuticular structures. The most notable aberration is the granular nature of the head skeleton (Fig. 4B), but cuticle formation is also abnormal. For example, when removed from the vitelline membrane, mutant embryos are abnormal in shape and appear flaccid and ameboid, in contrast to the normally elongated hatched larva. The abnormalities are also evident in cuticle preparations (Fig. 4), which manifest distended bulges, rupture easily, and generally appear misshapen. Further defects are apparent in the mouth parts (Fig. 4B) and in the setal belts of the ventral cuticle (Fig. 4C): Both the mouth hooks and the denticles are poorly differentiated, and the denticles frequently appear disordered, with cases of reversed polarity and of two denticles formed in the same location. Clearly, genes regulated by Elf- 1 are involved in many aspects of cuticle specialization.

The tracheal network also appears abnormal (data not shown). The main trunks are farther apart than usual, appear patchy, and rarely connect to the posterior spiracles. Patchiness is most likely the result of only parts of the tracheal tree filling with gas, suggesting a failure of some segmental tracheae to form, to interconnect, and/ or to fill with air because of structural defects. Because the tracheae are specializations of the ectoderm that secrete chitin, these results suggest further that Elf- 1 regulates multiple genes involved in the production of cuticle and cuticular derivatives by ectodermal cells.

In strong contrast to these cuticular defects, the formation and development of the nervous system appears normal in Elf- 1 mutant embryos, according to both morphological criteria and the distribution of specific antigens detected with antibodies. For example, the axonal scaffold detected by anti-horseradish peroxidase antibodies appears normal, as does the location of $f t z-$ or $U b x-$ expressing cells (Fig. 5). The expression of even-skipped and $e n$ have also been examined and appear to be wild type (data not shown).

\section{Elf-1 is grainyhead}

The cytological location of Elf- 1 did not correspond to that reported for any known gene. However, once the phenotype of Elf-1 mutations had been characterized we realized that it was very similar to that reported for a 


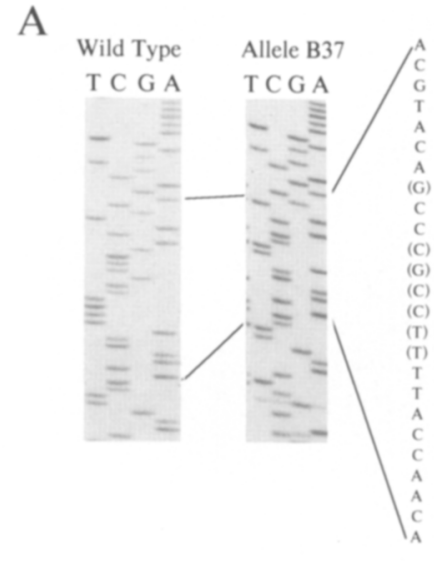

B

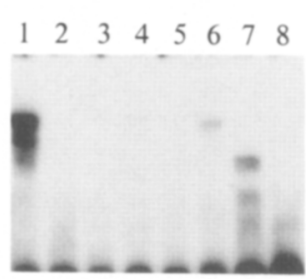

C $1 \begin{array}{llllllll}2 & 3 & 4 & 5 & 6 & 7 & 8\end{array}$

C 1

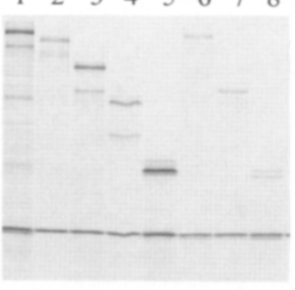

$\mathrm{D}$

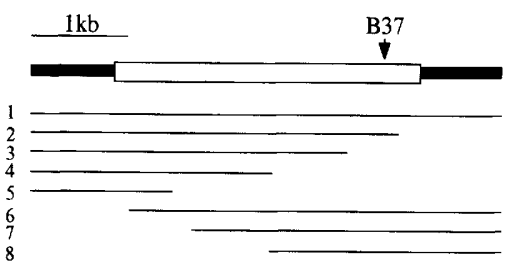

Figure 3. Molecular lesion in Elf-1 allele B37. (A) DNA sequence of the B37 allele reveals a deletion of $7 \mathrm{bp}$ in the coding sequence of Elf-1. Bases shown in parentheses (right) are absent from mutant as compared to wild type. This deletion causes a frameshift that will result in premature termination of the encoded protein. $|B-D|$. In vitro DNA-binding studies with truncated Elf- 1 show that the product of allele B37 would be inactive in DNA binding. Plasmids containing truncated cDNA clones $(D)$ were transcribed and translated in vitro $|C|$, and the polypeptide products were tested for DNA-binding activity $(B)$. Proteins encoded by a cDNA clone that is truncated at the $3^{\prime}$ end are not able to bind DNA fragments in vitro, although proteins encoded by clones with $5^{\prime}$ truncations still bind DNA. In the diagram of cDNA clones $(D)$ the starting cDNA is shown at the top. The open rectangle indicates coding sequence, and the site of the mutation in allele B37 is indicated. Truncated cDNAs are shown below the diagram, with numbered lines representing sequences used to produce the correspondingly numbered proteins shown in $B$ and $C$. Proteins produced by in vitro transcription and translation of truncated cDNA clones in the presence of $\left[{ }^{35} \mathrm{~S}\right]$ methionine were analyzed on an SDS-polyacrylamide gel $|C|$. Binding activities of unlabeled products synthesized in parallel were tested by using a ${ }^{32} \mathrm{P}$-labeled oligonucleotide encompassing the Elf-1-binding site $(B)$. The DNA/protein complexes, separated from unbound DNA using a native acrylamide gel, are detected with the products of plasmids $1,6,7$, and 8 only. The unbound oligonucleotide has been run off the gel. The label detected at the bottom edge results from a nonspecific binding activity in the extract. Similar results were obtained in two other experiments with different truncated cDNA clones.

gene in a screen for embryonic lethal genes on the second chromosome (Nüsslein-Volhard et al. 1984; R. Tearle, pers. comm.). This gene, referred to as l(2)IM45 and subsequently named grainyhead (grh), mapped by recombination to a position on the chromosome proximal to Elf1. Nevertheless, we crossed the Elf- 1 alleles to available grh alleles to test whether they might represent the same gene. All four Elf- 1 alleles fail to complement, indicating that Elf-1 does correspond to grh (Table 1). Therefore, in accordance with convention, we suggest that the gene encoding Elf-1, which has also been called NTF-1, should be referred to as grh. For the purposes of this paper we will refer to the protein encoded by the locus as Elf-1 and the gene as Elf-1/grh.

\section{Effect of Elf-1/grh mutations on Ddc expression}

Elf- 1 was isolated on the basis of its binding to element I, which has a major role in nervous system expression of $D d c$ (Bray et al. 1989). Surprisingly, endogenous Ddc expression, as assayed by antibody staining, is wild type in the nervous system of Elf-1/grh mutant embryos (Fig. 6C). Our ability to detect failures in $D d c$ expression was confirmed by using a strain with a $D d c$ gene that is disabled in neuronal expression because of a 2-bp mutation in element I (Fig. 6B). We conclude that Elf-1 does not mediate the nervous system expression of $D d c$, which is so severely impaired when element $I$ is mutated.

$D d c$ is also expressed in the epidermis during late stages of embryogenesis when the cuticle is being secreted. To analyze the effect of Elf- $1 / \mathrm{grh}$ mutations on $D d c$ expression in this and other tissues, we used a DdclacZ reporter gene construct (see Materials and methods). Expression of $\beta$-galactosidase can be assayed by using a histochemical stain that overcomes the problem of cuticle interfering with antibody detection methods. Like the endogenous $D d c$ gene, this construct is expressed in the epidermis and nervous system in wildtype embryos (although this fusion gene only leads to expression of $\beta$-galactosidase in a subset of the neurons normally expressing $D d c$; data not shown). $\beta$-Galactosidase is also detectable in the gut, but this activity is endogenous at least in part because it occurs in embryos that do not contain the fusion gene. Elf-1/grh mutant embryos, which can be distinguished by their head skeleton abnormalities, retain expression in the nervous system but do not express $\beta$-galactosidase in the epidermis (Fig. 7). These results were obtained with two different Elf-1/grh alleles (B37 and B32), including the allele that results in a trucated Elf- 1 protein. We conclude that Elf- 1 is required for the expression of $D d c$ in the embryonic epidermis.

\section{Effects of Elf-1/grh mutations on expression of other genes}

Three other genes containing Elf-1-binding sites have been identified: $U b x, f t z$, and en (Soeller et al. 1988; Dynlacht et al. 1989). Antibodies were used to analyze the expression of $U b x$ and $f t z$ in Elf-1/grh mutant embryos. Expression of both genes appears normal in the nervous system and epidermis: No gross changes in the domains of $U b x$ or $f t z$ expression are seen in Elf-1/grh mutant embryos, and no alterations in the cellular pattern can be detected (e.g., Fig. 5). Given the number of cells expressing $U b x$ in each segment, however, it re- 


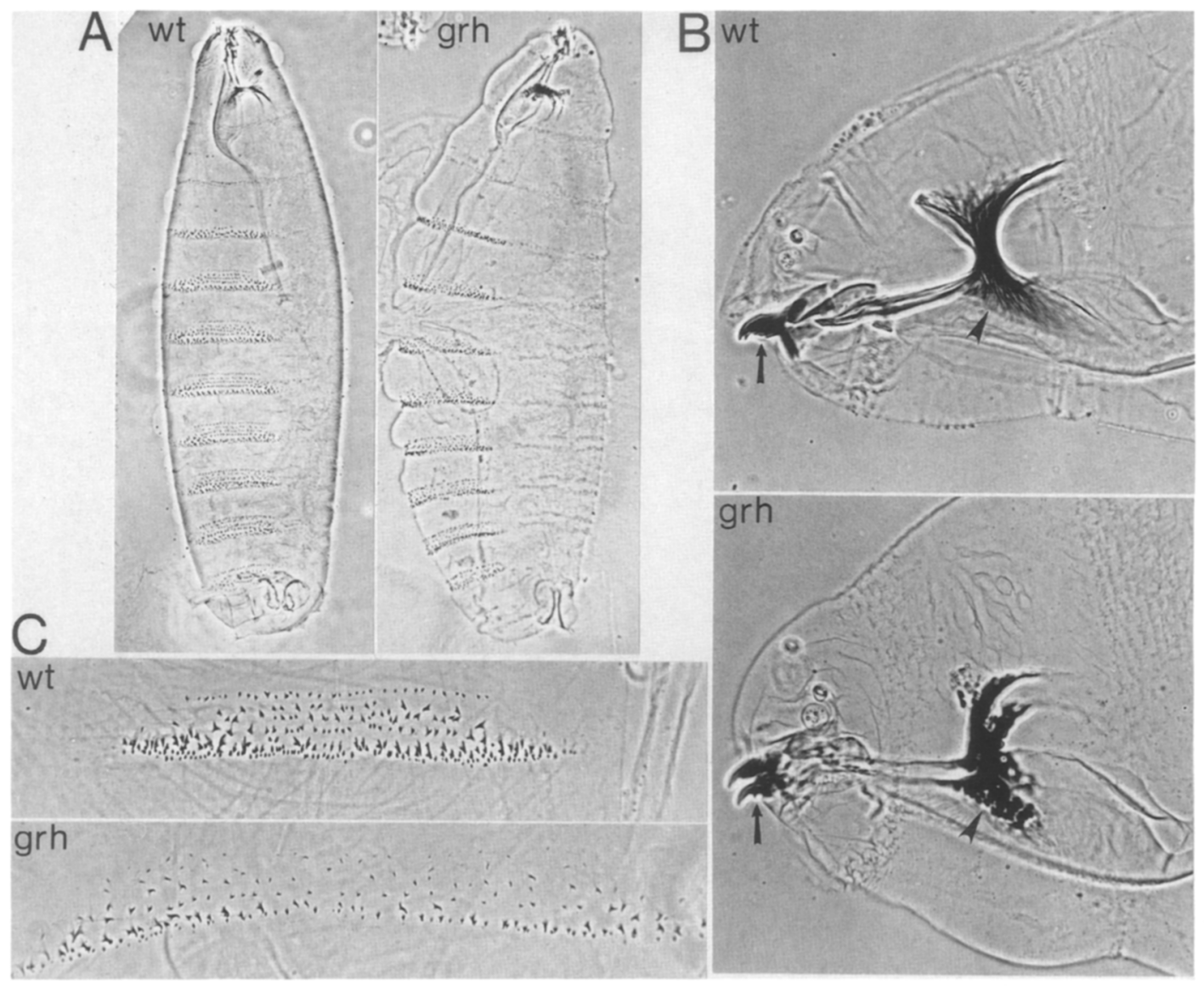

Figure 4. Cuticle preparations from Elf-1/grh alleles reveal multiple defects. Aspects of cuticle pattern of wild-type /wt $/$ and Elf-1/grh (grh) embryos. $(A)$ Ventrolateral aspect shows that the cuticle of Elf-1/grh mutant embryos is bulging and distended compared to that of wild type. $(B)$ Head structures: The head skeleton of Elf-1/grh embryos is reduced and has an unusual globular appearance. The ventral arm of the head skeleton is indicated by an arrowhead; the small arrows mark the mouth hooks, which are much smaller than usual in the mutant. $|C|$ Ventral aspect of cuticle in A3 showing denticles: The Elf-1/grh mutants have disordered and small denticles. The embryos shown are $g r h^{B 37} / D f 7$. Phase-contrast photographs.

mains possible that $U b x$ expression might be altered in a small number of individual cells. For our analysis of en expression we used an $e n-l a c Z$ gene fusion construct (Hama et al. 1990). In both the nervous system and epidermis of mutant embryos we observed the same segmentally repeating pattern of $\beta$-galactosidase expression as seen in wild-type embryos (Fig. 8). The expression of en-lac $Z$ in the epidermis of Elf-1/grh mutant embryos shows that although there is no epidermal $D d c-l a c Z$ expression, epidermal cells are still present in the mutant embryo. However, at late stages of embryogenesis the levels of $\beta$-galactosidase activity do not appear to be quite wild type in the mutant embryos. They are enhanced in subcuticular peripheral nervous system cells relative to epidermal cells. Although this may reflect a requirement for Elf-1, it is most likely the result of an increase in the accessibility of subcuticular structures to the $\beta$-galactosidase substrate because of flaws in the mutant cuticle. Prior to cuticle deposition (stage 15) both the levels and pattern of en-lacZ expression appear to be wild type (data not shown). In summary, the results with
$U b x, f t z$ and, possibly, en provide additional evidence that Elf- 1 protein binding in vitro does not correlate with effects of Elf-1/grh mutants in vivo.

\section{Discussion}

In vitro vs. in vivo functional assays of the Elf-1 transcription factor

The results presented here emphasize the importance of testing the essential functions of a transcription factor in the organism. The molecular properties and in vitro actions of DNA-binding proteins can suggest a potential role, but their actual function during development can only be ascertained by perturbing these proteins in vivo. For this purpose, we have taken advantage of the sophisticated genetics of Drosophila.

Elf- 1 was identified on the basis of its in vitro interaction with a sequence element that is essential for transcription of the $D d c$ gene only in the nervous system of Drosophila (Bray et al. 1988, 1989). Elf-1 was subse- 

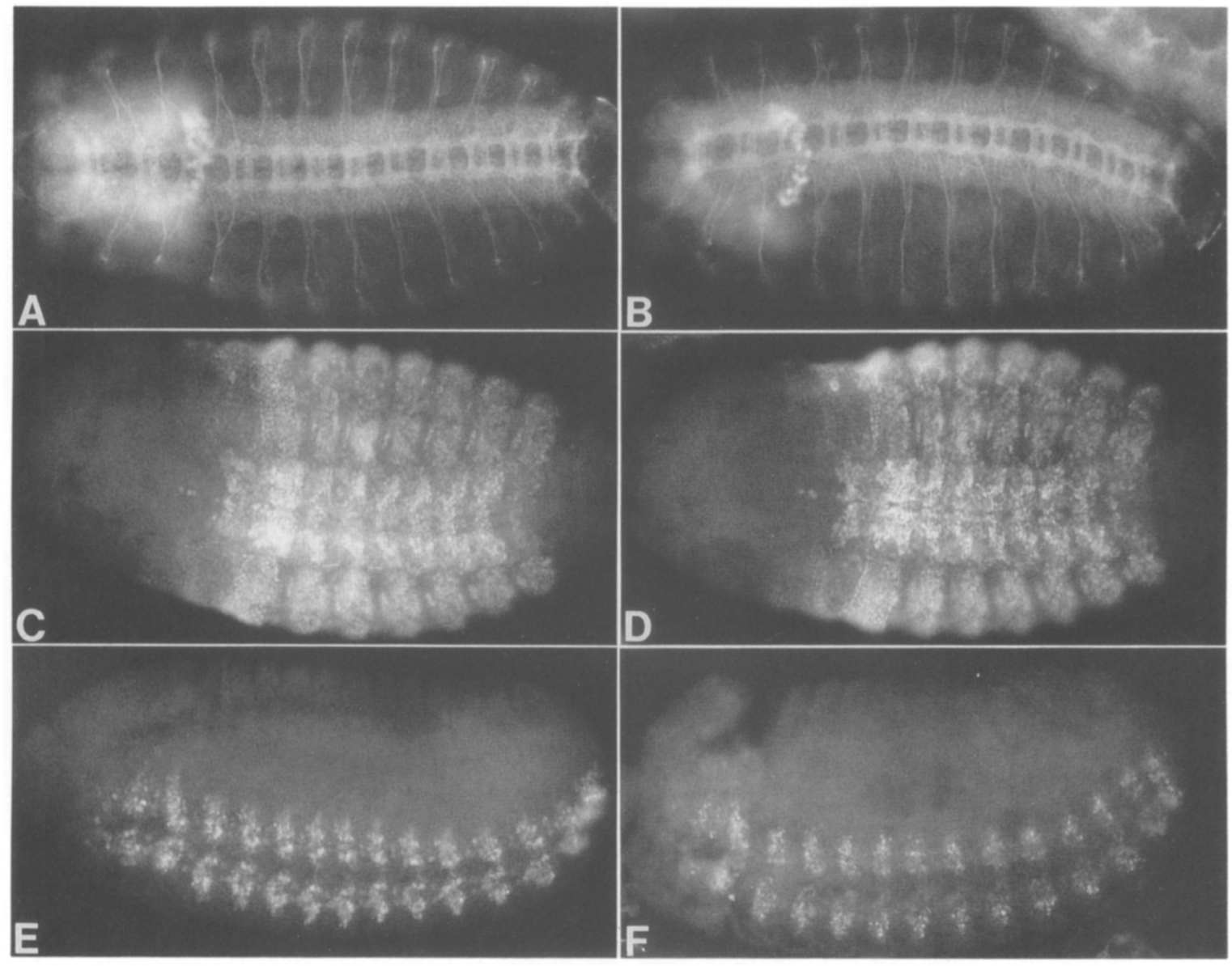

Figure 5. Axonal scaffold and distribution of $U b x$ and $f t z$ proteins appear unaffected by Elf-1/grh mutations. The expression of three antigens in wild-type $(A, C, E)$ and Elf-1/grh mutant $(B, D, F)$ embryos was analyzed. The anti-horseradish peroxidase antibody recognizes an antigen present on the axonal scaffold of wild-type $(A)$ and Elf-1/grh mutant $(B)$ embryos. No differences are distinguishable in mutant embryos. Expression of $U b x(B, D)$ and $f t z(E, F)$ proteins also appears identical in wild-type and mutant embryos. Mutant embryos were of the genotype $g r h^{B 37} / D f 7$ and were identified by the absence of the $\beta$-galactosidase-expressing CyO balancer chromosome in double-label experiments as described in Fig. 2. Similar results were obtained with alleles B32 and B35.

quently shown to be capable of activating in vitro transcription from this and other developmentally regulated genes, $U b x$ and $f t z$ (Dynlacht et al. 1989). To test the hypothesis that this protein is responsible for activating expression of these genes in vivo we have generated mutations in the Elf- 1 gene. These mutations are embryonic

Table 1. Elf-1 is allelic to grh

\begin{tabular}{lcc}
\hline Alleles tested & $C y^{-}$progeny & $\mathrm{Cy}^{+}$progeny \\
\hline B37 $\times g^{300}$ & 395 & 0 \\
B32 $\times$ grh $^{300}$ & 392 & 0 \\
B35 $\times$ grh $^{300}$ & 441 & 0 \\
B28 $\times g^{300}$ & 297 & 0 \\
B37 $\times$ grh $^{370}$ & 351 & 0 \\
B32 $\times g^{370}$ & 182 & 0 \\
B37 $\times g r h^{380}$ & 465 & 0 \\
B32 $\times g r h^{380}$ & 148 & 0 \\
\hline
\end{tabular}

lethal, indicating that Elf-1 is essential, and correspond to a previously defined lethal locus, grh. Using $D d c-l a c Z$ fusion genes we have shown that the Elf-1/grh mutations do have an effect on expression from the $D d c$ promoter in the embryo. However, contrary to predictions, this effect is limited to the epidermal expression of $D d c$; there is no apparent effect on $D d c-l a c Z$ or endogenous $D d c$ expression in the nervous system of Elf-1/grh mutant embryos. No change in $U b x$ or $f t z$ expression was detectable either. How can the disparate in vitro and in vivo results be reconciled?

Point mutations in the cis-acting element I of $D d c$ prevent $D d c$ expression in the embryonic CNS even though mutations in the putative trans-factor, Elf-1, do not. Clearly we must postulate the existence of another factor necessary for $D d c$ expression in the CNS. The simplest hypothesis is that this putative CNS factor interacts with element $I$, without involvement of Elf- 1 . There are examples in several genes of two or more factors binding to overlapping or indentical sites in the reg- 


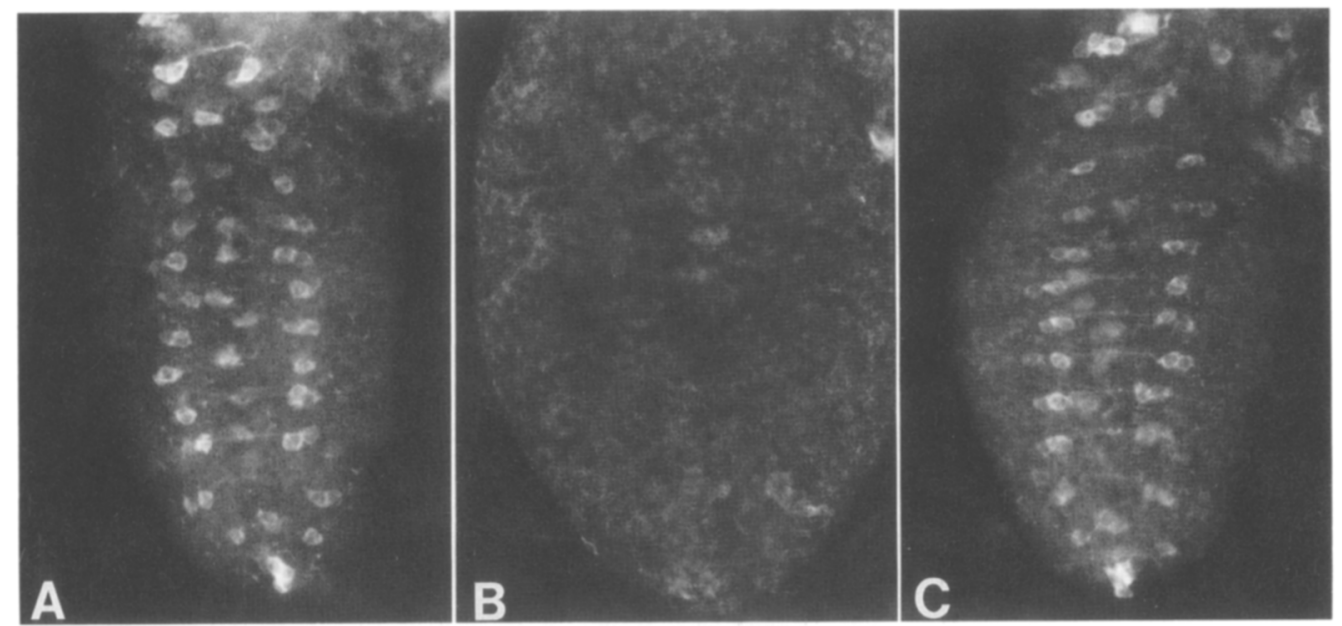

Figure 6. $D d c$ expression in the nervous system of Elf-1/grh mutant embryos is wild type. The CNS was dissected from embryos of wild-type $(A)$, strain $\mathrm{ml}(B)$, and Elf-1/grh $\mid C)$ mutant $\left(g r h^{B 37} / D f 7\right)$ genotypes, and the levels of $D d c$ expression were visualized with an anti- $D d c$ antiserum and a rhodamine-conjugated anti-rabbit secondary antibody. Strain $\mathrm{ml}$ is a P-element transformant strain described previously (Bray et al. 1989), which contains a Ddc gene with 2-bp mutations in element I, an Elf-1-binding site. Mutations in element $I$ disrupt $D d c$ expression in the nervous system $|B|$; mutations in Elf-1 have no effect on $D d c$ expression $\langle C|$. Similar results were obtained with three other Elf-1/grh alleles.

ulatory DNA (e.g., Poellinger and Roeder 1989; Stanojevic et al. 1989; Pierani et al. 1990). The alternative possibility, that the CNS factor acts with Elf- 1 and can stabilize the binding between mutant Elf-1 and element I, seems unlikely as all four different alleles of Elf-1/grh fail to cause any changes in neuronal $D d c$ expression. An additional possibility that must be considered is the presence of maternally provided Elf- 1 , which can function to turn on $D d c$ expression in the CNS in the absence of zygotic protein. However, maternal Elf-1 has not been detected. The mRNA and protein first appear in embryos during germ-band shortening (Bray et al. 1989; Dynlacht et al. 1989|. We are thus led to postulate the existence of an unidentified CNS factor even though Elf- 1 is the only detectable protein in embryonic extracts that binds to element I in vitro (Bray et al. 1989). The putative CNS factor could have failed detection if it is only present in a small number of cells, for example, the $D d c$-expressing neurons of the CNS. Detection and/or disruption of spatially compartmented molecules are inherent limitations of in vitro studies with extracts from complex cell populations, such as whole embryos.

Unlike their effect on expression in the nervous system, mutations in the cis-acting element I have little, if any, detectable effect on $D d c$ expression in the epidermis (Scholnick et al. 1986; Bray et al. 1988; S.J. Bray, unpubl.). This seems paradoxical, in view of the fact that these mutations interfere with in vitro binding of Elf- 1 to element I (Bray et al. 1988; 1989) and that Elf-1 is needed for normal expression in the epidermis in vivo. Either Elf- 1 acts on $D d c$ indirectly in the epidermis, or element I is not the only Elf-1 binding site in the $D d c$ promoter. It is not uncommon to find multiple binding sites for a single transcription factor within the regulatory DNA of a gene. In several instances one or more of the sites appear to be functionally redundant (e.g., Dudler and Tra- vers 1984; Topol et al. 1985; Stanojevic et al. 1989; Jiang et al. 1991; Regulski et al. 1991). We have recently scanned the entire $D d c$ gene with an in vitro binding assay and have detected additional strong Elf-1-binding sites (F.C. Kafatos, unpubl.). Furthermore, if large deletions are introduced into the regulatory DNA of the $D d c$ gene, the presence of element I does influence the levels of expression in the epidermis, albeit weakly (Bray et al. 1988). These data suggest that there are redundant Elf-1binding sites within the $D d c$ gene; it remains to be determined whether it is necessary to mutate more than one Elf-1-binding site to alter Ddc expression in the embryonic epidermis or whether a single high-affinity site is crucial. It is instructive that interaction with element I led to the cloning of Elf- 1 , even though this is neither the strongest interaction of which Elf- $I$ is capable nor, apparently, the crucial interaction in vivo.

Our results raise questions about the significance of Elf-l binding to the $U b x, f t z$, and en promoters. Demonstration of in vitro binding and transcriptional activation by this factor (also called NTF-1) was based on nuclear extracts prepared from embryos (Biggin and Tiian 1988; Dynlacht et al. 1989). Nevertheless, Elf-1 does not appear to have an essential role in the transcription of $U b x$ or $f t z$ in any part of the embryo. The Elf-1/grh mutations also leave expression of $e$ largely unaffected. It seems likely that the en Elf-1-binding site is functionally important because, like the $D d c$ element $\mathrm{I}$, it is conserved in a distantly related Drosophila species (Kassis et al. 1989|. Given its similarity to the element I sequence, this might also be a target for the putative CNS factor, while its binding to Elf- 1 itself is fortuitous. This argument could also hold for the Elf-1-binding sites in $U b x$ and $f t z$, although these show less clear sequence similarities to $D d c$ element I and may have no functional role in mediating in vivo expression of $U b x$ and $f t z$. 


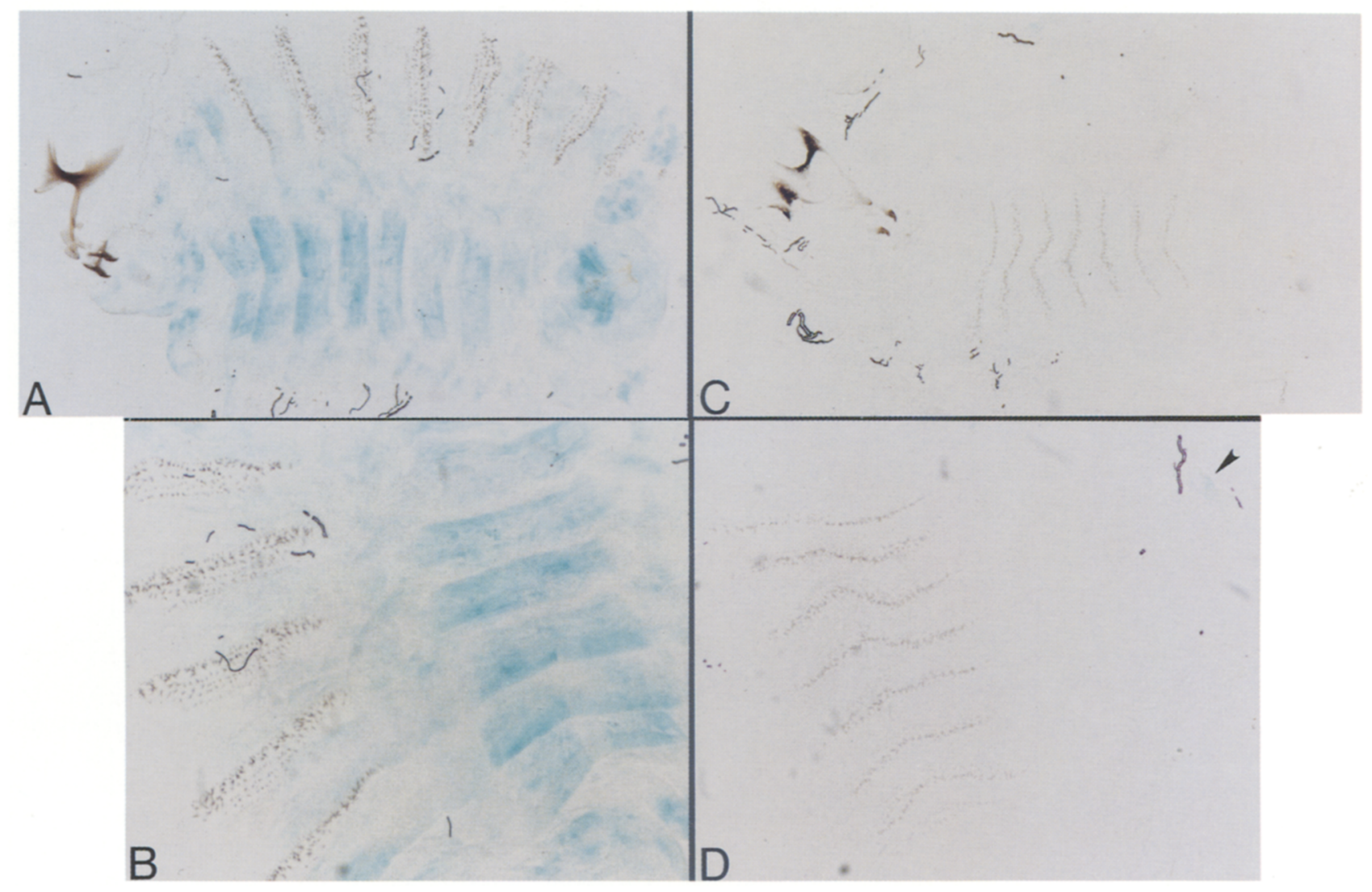

Figure 7. Elf- 1 is required for $D d c$ expression in the epidermis. $\beta$-Galactosidase expression from a $D d c-l a c Z$ fusion gene is detectable in embryos with wild-type head skeletons $(A, B)$ but not in embryos with defective head skeletons characteristic of Elf- $1 / \mathrm{grh}$ mutations $(C, D)$. A $D d c-l a c Z$ gene inserted on chromosome $2 \mathrm{~L}$ was recombined onto chromosomes carrying Elf-1/grh mutations. Embryos from a $D d c-l a c Z g r h / C y O \times D f 7 / C y O$ cross were examined for $D d c$ promoter activity by using a histochemical stain for $\beta$-galactosidase. The epidermis of the embryos has been slit open, the internal tissue removed, and the cuticle and underlying tissues flattened. The arrowhead in $D$ indicates a small amount of gut tissue remaining in which $\beta$-galactosidase expression is detectable. Two Elf-l/grh alleles (B32 and B37) were used and gave identical results. Mutant embryos were allele B37.

One can never discount the possibility of subtle defects, but we have not observed any malformations in the embryonic nervous system associated with Elf-1/grh mutations, even though Elf-1 is normally expressed within some cells in this tissue. We do not know what role, if any, this factor plays in the nervous system. Clearly, it is neither necessary nor sufficient for expression of $D d c, U b x, f t z$, or en in the embryonic nervous system. Expression of these genes appears unaffected by Elf-1/grh mutations, and Elf-1-expressing cells that do not express the genes exist in the wild type (Bray et al. 1989 and unpubl.). However, Elf-1 might have an essential neuronal function later in development. Critical evaluation of the role of Elf- 1 during later stages of development will require generation of mosaic nervous systems containing patches of mutant tissue or isolation of Elf-1/grh alleles that are temperature sensitive or only affect postembryonic development.

\section{Involvement of Elf-1 in cuticular morphogenesis}

In contrast to the results on the nervous system, we have obtained clear evidence that Elf- 1 is required in the embryonic epidermis and that it coordinates, directly or indirectly, the expression of multiple genes involved in th? complex process of cuticular morphogenesis. $D d c$ is one of the genes regulated by Elf- 1 in this tissue, but additional target genes clearly exist. Null $D d c$ mutants have underpigmented mouth hooks and denticle belts, but no other obvious cuticular defects, and can survive into larval instars if manually removed from the vitelline membrane (Valles and White 1986; Wright 1987). Elf-1/grh mutants have disorganized cuticular structures and weak cuticles and fail to survive if removed from the vitelline membrane. Both the pigmented sclerotinized structures and the colorless cuticle that ensheathes the body, as well as the tracheae, are affected by Elf-1/grh mutations. On the other hand, the underpigmentation of cuticular structures is not as severe in Elf-1/grh mutants as in the case of $D d c$ null mutations. This suggests that even within the epidermis Elf-1 may not be required in all cells for $D d c$ expression. Indeed, antibody staining reveals residual $D d c$ protein in some cells surrounding the head skeleton of Elf-1/grh mutant embryos (data not shown). 


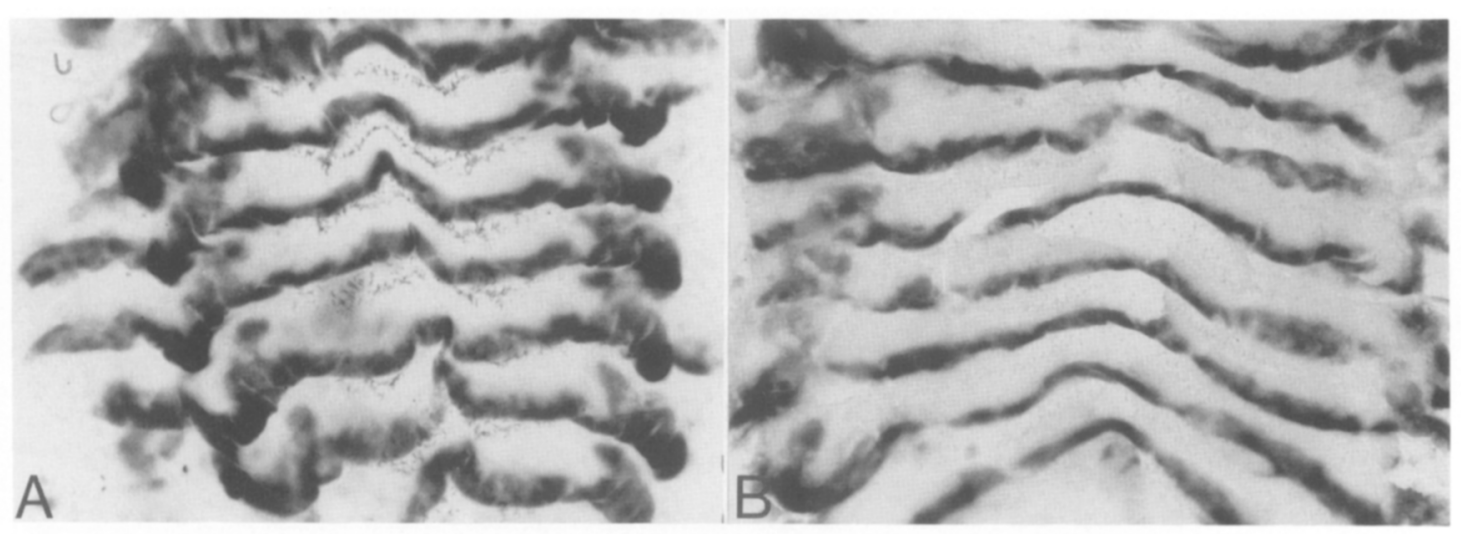

Figure 8. An en-lacZ fusion gene is expressed in the epidermis of Elf-1/grh mutant embryos. $\beta$-Galactosidase is detectable in stripes in the epidermis from both wild-type $(A)$ and mutant $(B)$ en-lacZ, grh $h^{B 37} / D f 7$ embryos, showing that Elf-1 is not essential for the epidermal expression of en. A P-element strain (ryxho25) containing an insertion of an en-lacZ fusion gene at the en locus expresses $\beta$-galactosidase in the equivalent pattern to that of the wild-type en gene (Hama et al. 1990). This locus was crossed onto Elf-1/grh mutant chromosomes by recombination, and expression of $\beta$-galactosidase in the epidermis was assayed in embryos of wild-type and mutant phenotype as in Fig. 7. All four Elf-1/grh alleles were tested for effects on en-lac $Z$ and gave results identical to those for allele B37 presented here.

Although we do not know which genes, other than $D d c$, are direct or indirect Elf- 1 targets in the epidermis, the mutant phenotypes suggest several candidates. For example, flimsy, friable cuticles as found in Elf-1/grh mutants are also seen in embryos lacking Punch and 1(2)amd (see Wright 1987). The product of 1(2)amd, which appears to be involved in the formation of colorless cuticle (Wright 1987), is closely related to the $D d c$ enzyme and presumably arose from a gene duplication (Eveleth and Marsh 1986). Regulation by Elf-1 may predate the duplication that gave rise to the modern $D d c$ and 1(2)amd genes. Punch and Elf-1/grh mutations cause similar defects in both the tracheal system and epidermis (Reynolds and O'Donnell 1987). The Punch product catalyzes the synthesis of a cofactor required by several enzymes including tyrosine hydroxylase. The similarity between the phenotypes of Punch and Elf-1/grh may indicate that Elf-l regulates Punch or, alternatively, that it regulates the enzymes that require the Punch product. It is important to note, however, that while Elf-1/grh-deficient embryos manifest some phenotypic characteristics similar to those of Punch and 1(2)amd embryos, they do not exhibit all of the same defects. If Elf- 1 is involved in regulating the expression of such genes it is most likely only affecting expression in certain tissues and cell types, as is the case with its effect on Ddc.

Other aspects of the Elf-1/grh phenotype appear novel, suggesting that Elf-1 may act on as yet unknown genes. This is the case for the head skeleton abnormalities. Unlike mutations affecting cuticle synthesis, which cause loss of pigmentation and sturdiness of the head skeleton without affecting the pattern, the head skeleton of Elf$1 / g r h$ mutants has a very different structure, appearing globular rather than linear. This may represent misregulation of genes required for synthesis of structural components, or it could reflect a problem in the communication between the cells that secrete the structure. A problem in cell communication or the interpretation of positional information is also suggested by the disordered array of the denticles within the denticle belts of the ventral cuticle. Studies of mosaics indicate that local cell interactions are important in the interpretation of positional information in the epidermis (Gergen and Wieschaus 1985). A breakdown in these local communications could explain the sporadic denticles with reversed polarity and the disordered appearance of the denticles.

Now that many of the molecules involved in the hierarchy determining the early stages of embryonic patterning have been identified, attention is shifting to what occurs downstream of these molecules to lead to the morphological complexity of the organism. Elf- 1 appears to be a very downstream regulatory component. The identification of the gene encoding this transcription factor, coupled with the immunochemical and molecular tools available for its study, should lead to an understanding of how Elf- 1 regulates the final stages of embryonic epidermal differentiation and the complex morphogenesis of the cuticle.

\section{Materials and methods}

\section{Drosophila strains}

For a description of marker and balancer chromosomes, see Lindsley and Grell (1968) and Lindsley and Zimm (1985, 1990). $D f(2 R) P c l^{7 B} / C y O$ and $D f(2 R) P c 1^{11 B} / C y O$ were obtained from 1 . Duncan (1982), and grh alleles (b pr cn wx $\mathrm{wrt}^{\mathrm{wt}} \mathrm{grh}^{300} \mathrm{bw} / \mathrm{CyO}$ bw and $b$ pr cn wx $\left.{ }^{w t} g r h^{370} b w / C y O R o i b w\right)$ were from R. Tearle and were generated by ethylmethane sulfonate (EMS) mutagenesis. The en-lacZ transformant line ryxho25 was from the laboratory of T. Kornberg (Hama et al. 1990). All other stocks were from the collection maintained at The Biological Laboratories (Harvard University). Flies were cultured as described previously (Smolik-Utlaut and Gelbart 1987). Unless otherwise 
stated, crosses were maintained at $25^{\circ} \mathrm{C}$. Preparation of cuticles for phase microscopy was as described by Wieschaus and Nüsslein-Volhard (1986).

\section{Mutagenesis}

Two hundred aged males isogenic for $d p \mathrm{cn} b w$ second chromosome were exposed to $0.3 \% \mathrm{EMS}$ ( $\mathrm{vol} / \mathrm{vol})$ in $0.3 \mathrm{M}$ sucrose for 24 $\mathrm{hr}$ (Lewis and Bachar 1968) and were then mated to Sp B L/CyO virgin females (10 males and 30 females per bottle). F1 $d p c n$ $b w / C y O$ males were mated individually to two $D f(2 R) P c l^{7 B} /$ $\mathrm{CyO}$ virgin females and maintained at $29^{\circ} \mathrm{C}$. A total of 3260 single matings were set up, of which $5.2 \%$ were sterile. Each cross was scored for absence of straight-winged $\left(\mathrm{Cy}^{+}\right)$flies indicative of a lethal mutation in the region uncovered by the deficiency. Forty-five vials were identified, which lacked $\mathrm{Cy}^{+}$ progeny, $1.4 \%$ of the total. The 45 putative lethal mutations were retested against $D f(2 R) P C I^{7 B} / C y O$ at $29^{\circ} \mathrm{C}$, and 35 of those tested still failed to produce $\mathrm{Cy}^{+}$progeny. These alleles were then crossed at $29^{\circ} \mathrm{C}$ to $\mathrm{Df}(2 \mathrm{R}) \mathrm{PCl^{11B }} / \mathrm{CyO}$ to identify the subset of alleles that were not located within the region removed in this deficiency. Thirteen alleles were identified that did give $\mathrm{Cy}^{+}$progeny from this cross; these alleles were then mated inter se at $29^{\circ} \mathrm{C}$ to assign the mutations to complementation groups. The alleles were subsequently tested for temperature sensitivity and were found to be lethal at all temperatures. All further crosses were maintained at $25^{\circ} \mathrm{C}$.

\section{Immunohistochemistry and immunofluorescence}

Immunological detection of proteins in embryos was carried out essentially as described previously (Bray et al. 1989), except that the buffer used for the fixation was $160 \mathrm{mM} \mathrm{KCl}, 40 \mathrm{~mm} \mathrm{NaCl}$, $4 \mathrm{mM} \mathrm{Na}_{3}$ EGTA, $1 \mathrm{~mm}$ spermidine- $\mathrm{HCl}, 0.4 \mathrm{~mm}$ spermine- $\mathrm{HCl}$, $0.2 \% \beta$-mercaptoethanol, and $30 \mathrm{~mm}$ PIPES $(\mathrm{pH} 7.4 \mid$. Embryos were staged according to Campos-Ortega and Hartenstein (1985). The primary antibodies used were as follows: Anti-Elf-1 monoclonal BF1 diluted 1: 6 (Bray et al. 1989), anti-Ddc rabbit antiserum diluted $1: 50$ (Beall and Hirsh 1987), anti- $\beta$-galactosidase rabbit antiserum diluted 1:2000 (gift of R. Holmgren), anti-ftz rabbit antiserum diluted $1: 300$ (gift of Sean Carroll), and anti- $U b x$ monoclonal FP3.38 diluted 1:6 (White and Wilcox 1984). Fluorescent secondary antibodies were DTAFconjugated sheep anti-mouse diluted 1 : 100 (Jackson Immunologicals) and rhodamine-conjugated goat anti-rabbit diluted $1: 250$ (TAGO). FITC-conjugated anti-horseradish peroxidase was from Cappell. For visualization of immunofluoresence, embryos were mounted in Citiflor. Horseradish peroxidase-conjugated secondary antibodies (goat anti-mouse used at 1:1000, Bio-Rad) were detected with $0.5 \mu \mathrm{g} / \mathrm{ml}$ of diaminobenzidine as substrate in the presence of $0.03 \% \mathrm{NiSO}_{4}$ and $0.06 \% \mathrm{H}_{2} \mathrm{O}_{2}$. The stained embryos were dehydrated with an ethanol series $130 \%$, $70 \%, 100 \%$, rinsed twice in isopropanol and once in xylene, and finally transferred to a drop of DePeX (BDH). Stained embryos were photographed on a Zeiss axiophot microscope with DIC optics.

For analysis of late embryonic structures the embryos were dissected with tungsten needles and the tissues were fixed in $4 \%$ formaldehyde in fixation buffer for $20 \mathrm{~min}$ in depressionwell plates. Following fixation the dissected tissues were treated in the same way as whole embryos except all manipulations were carried out in depression-well plates.

\section{Analysis of the molecular lesion in allele B37}

The protocols for standard molecular biology techniques were as described in Sambrook et al. (1989). Restriction enzymes and other enzymes used for molecular biology were purchased from New England Biolabs or Boehringer Mannheim Biochemicals except where indicated otherwise. Oligonucleotides were synthesized by A. Khoury on a Cyclone Plus synthesizer. The following section describes some of the specific methods used.

The fragment of Elf- 1 containing a lesion in allele B37 was identified by using the procedures described by Gray et al. (1991; see also Fischer and Lerman 1983; Curtis et al. 1989). Briefly, genomic DNA from adults of balanced stocks carrying the mutant alleles and from the parental strains was digested with HaeIII and electrophoresed on a formamide/urea gradient denaturing acrylamide gel. The DNA was electroblotted from the gel onto nylon filters and probed with Elf-1 cDNA fragments. A band with altered mobility in strain B37 compared to the parental chromosomes was detected. This fragment was localized to a l-kb genomic EcoRI fragment (the genomic library was constructed by using DNA from the isogenic $d p c n b w$ strain used for the mutagenesis and was kindly provided by $R$. Blackman and W. Gelbart) which contained five HaellI fragments. Most of the fragments were very small, and only two appeared likely to correspond to the one detected on the denaturing gels. Probes were prepared from both fragments by using PCR to identity the HaeIII fragment with altered mobility. Primers for PCR were synthesised corresponding to 21-bp sequences located just outside the HaeIII fragment, with the aim of amplifying the sequence from genomic DNA of mutant embryos.

Nucleic acids were prepared from 10 homozygous B37 embryos by grinding frozen embryos in a 50/50 mixture of phenol/ grind buffer $[7 \mathrm{~mm}$ urea, $2 \%$ SDS, $10 \mathrm{~mm}$ Tris-Cl $(\mathrm{pH} 8), 1 \mathrm{~mm}$ $\mathrm{Na}_{2}$ EDTA, $0.35 \mathrm{~mm} \mathrm{NaCl}: 25 \mu$ l of buffer per 10 embryos] that had been prewarmed to $60^{\circ} \mathrm{C}$. A half volume of chloroform was then added. The aqueous phase was then re-extracted with chloroform, and the nucleic acids were precipitated with ethanol. Half of the resuspended nucleic acids were taken for PCR amplification, using Amplitaq and the conditions recommended by the manufacturer (Perkin-Elmer Cetus). Annealing was at $60^{\circ} \mathrm{C}$ (1 min), extension was at $72^{\circ} \mathrm{C}(1 \mathrm{~min} 45 \mathrm{sec})$, and melting was $94^{\circ} \mathrm{C}(1 \mathrm{~min})$. Thirty cycles of amplification were carried out, and the tubes were then incubated at $25^{\circ} \mathrm{C}$ to allow full renaturation. Any ragged or protruding ends on the PCR products were filled in by using Klenow enzyme, and the products were analyzed on a $10 \%$ native polyacrylamide gel in $1 \times$ TBE buffer. Staining of the gel with ethidium bromide revealed a major band of appropriate molecular weight which was excised from the gel for cloning and subsequent sequencing (using U.S. Biochemical Sequenase; Tabor and Richardson 1987). A total of eight different clones, which were derived from two independent PCR amplification reactions, were sequenced.

\section{In vitro binding of truncated Elf-1 proteins}

The cDNA clones used to produce truncated Elf-1 proteins were from a series of exonuclease III deletions of Elf- 1 cDNA clone $\mathrm{N}$ prepared for sequencing the cDNA (Bray et al. 1989). The procedures used to produce the proteins in vitro by in vitro transcription and in vitro translation were also described, as were the conditions for DNA-binding assays and analysis of the protein products on SDS-polyacrylamide gels.

\section{lacZ fusion genes and $\beta$-galactosidase detection}

The strain containing the en-lacZ fusion gene was ryxho25 from the laboratory of T. Kornberg (Hama et al. 1990), which has the transposon inserted in the en locus at $48 \mathrm{~A}$ on chromosome $2 \mathrm{~L}$. This locus was recombined onto chromosomes carrying the 
Elf-1/grh alleles (genotype $d p c n$ grh $b w$ ) by scoring for recombination between $c n$ (43E) and $b_{w}$ (59D4-E1) with the chromosome net $d p p^{h o} d p S p c n e n^{2} b w$. The presence of the ryxho25 transposon could also be detected because it results in a wingvein phenotype when in trans to an en mutation. Males carrying recombinant chromosomes with the ryxho25 locus were then tested for lethality over grh alleles. Several different recombinant chromosomes were recovered for each of the four Elf-1/grh alleles; and in all cases, at least two different chromosomes were tested for effects of Elf-1/grh mutations on en-lacZ expression.

The strain containing the $D d c-1 a c Z$ fusion (Ddc-lacZ.H10) was one of a series of $D d c-l a c Z$-expressing strains, some of which have been described previously (Bray et al. 1988). The starting plasmid (DH43G) contained P-element transposon ends flanking an $h s p 70 / l a c Z$ fusion gene and an $A d h$ gene (for a selectable marker). The $h s p 70 / l a c Z$ fusion contained $1167 \mathrm{bp}$ of $h s p 70$ sequences from the PstI site $(+89)$ in the $5^{\prime}$-untranslated leader sequence to the $B g I I I$ site in the coding sequence $(+1256)$. $P s t \mathrm{I}$ linkers were ligated onto a fragment encompassing the $D d c$ promoter from a BglII site at -2200 to a $\mathrm{HpaI}$ site in the $5^{\prime}$ untranslated sequences $(+174 \mathrm{bp})$, and this was cloned into the PstI site in the $h s p>0$ leader sequence. The fusion therefore occurred in the untranslated sequences downstream of the transcription start site and incorporated the start of translation from the $h s p 70$ gene. The host strain used for transformation was $A d h^{f n 23} \mathrm{cn} p r$, and methods were as described previously (Bray and Hirsh 1986). In the strain Ddc-lacZ.H10 the P-element is inserted on the second chromosome (2L) close to $c n(43 E)$. This locus was recombined onto chromosomes carrying Elf-1/grh alleles $|d p c n g r h b w|$ by scoring for recombination between $d p$ and $b w$ with the chromosome net $d p p^{h_{o}} d p S p c n e n^{2} b w$ as described above, and subsequently scoring for $g r h$ and the $l a c Z$ transposon on the recombinant chromosomes. In all cases, at least two different recombinant chromosomes were used to study the effects of each $g r h$ allele on $D d c-l a c Z$ expression.

Histochemical detection of $\beta$-galactosidase activity was based on procedures described previously (Simon et al. 1985; Glaser et al. 1986). Activity was assayed in embryos at $\sim 22-24 \mathrm{hr}$, that is, at about the time when many wild-type embryos were hatching. Those that had not hatched were dissected manually from the chorion and vitelline membrane and all embryos were slit longitudinally with tungsten needles before fixation. Fixed embryos were incubated in staining solution $[0.2 \%$ 5-bromo-4chloro-3-indolyl- $\beta$-D-galactopyranoside, $10 \mathrm{~mm}$ sodium phosphate $\left(\mathrm{pH} 7.2\right.$ ), $150 \mathrm{~mm} \mathrm{NaCl}, 1 \mathrm{mM} \mathrm{MgCl} 2,3.1 \mathrm{mM} \mathrm{K}_{4}\left[\mathrm{Fe}(\mathrm{CN})_{6}\right]$, $3.1 \mathrm{~mm} \mathrm{~K}_{3}\left[\mathrm{Fe}(\mathrm{CN})_{6}\right], 0.3 \%$ Triton X-100] for $30 \mathrm{~min}(e n-l a c Z)$ or overnight (Ddc-lacZ) at $37^{\circ} \mathrm{C}$. The gut and other internal organs were then dissected away from the cuticle, leaving the epidermis and musculature attached. The cleaned cuticles were flattened under coverslips in Immumount (Shandon) and viewed on a Zeiss axiophot microscope by using bright-field optics and photographed with Kodacolor Gold film, ASA 100.

\section{Acknowledgements}

We thank Ian Duncan and Rick Tearle for providing Drosophila strains, and Rob White, Sean Carroll, and Bob Holmgren for gifts of antibodies. We are very grateful to all those in the Biolabs fly facility for their advice on genetics, in particular Rick Jones, Vern Twombly, and Laurel Raftery for many patient discussions. We thank Lorraine Lucas and associates for all their dedicated assistance. We are also grateful to David Smouse, who kindly looked at the nervous system antibody staining, and Dan Curtis, who gave invaluable help in providing the "break- through blots." We thank John Bashford and the AVA unit in Cambridge for much help with the photography and Bianca Klumpar for Figure 2. We are grateful to Nick Brown, Martin Shea, and Rob White for helpful comments on the manuscript, and S.J.B. thanks the many colleagues in the Kafatos lab who made work at the Biolabs so enjoyable. S.J.B. was the recipient of a National Science Foundation (NSF) Research Initiation Award. The work was also supported by an NSF grant to F.C.K. and, in its final stages, by a Medical Research Council project grant to S.J.B.

The publication costs of this article were defrayed in part by payment of page charges. This article must therefore be hereby marked "advertisement" in accordance with 18 USC section 1734 solely to indicate this fact.

\section{References}

Akam, M. 1987. The molecular basis for metameric pattern in the Drosophila embryo. Development 101: 1-22.

Beall, C.J. and J. Hirsh. 1987. Regulation of the Drosophila dopa decarboxylase gene in neuronal and glial cells. Genes \& Dev. 1: $510-520$.

Biggin, M. and R. Tiian. 1988. Transcription factors that activate the Ultrabithorax promoter in developmentally staged extracts. Cell 53: 699-711.

Bray, S.J. and J. Hirsh. 1986. The Drosophila virilis dopa decarboxylase gene is developmentally regulated when integrated into Drosophila melanogaster. EMBO I. 5: 2305-2311.

Bray, S.J., W.A. Johnson, J. Hirsh, U. Heberlein, and R. Tjian. 1988. A cis-acting sequence and associated binding factor required for CNS expression of the Drosophila melanogaster dopa decarboxylase gene. EMBO I. 7: 177-188.

Bray, S.J., B. Burke, N.H. Brown, and J. Hirsh. 1989. Embryonic expression of a family of Drosophila proteins that interact with a central nervous system regulatory element. Genes \& Dev. 3: 1130-1145.

Campos-Ortega, J.A. and V. Hartenstein. 1985. The embryonic development of Drosophila melanogaster. Springer Verlag, Berlin.

Curtis, D., S.H. Clark, A. Chovnick, and W. Bender. 1989. Molecular analysis of recombinant events in Drosophila. Genetics 122: 653-661.

Dudler, R. and A.A. Travers. 1984. Upstream elements necessary for optimal function of the $h s p 70$ promoter in transformed flies. Cell 38: 391-398.

Duncan, I. 1982. Polycomblike: A gene that appears to be required for the normal expression of the bithorax and Antennapedia gene complexes of Drosophila melanogaster. Genetics 102: 49-70.

Dynlacht, B., L. Attardi, A. Admon, M. Freeman, and R. Tjian. 1989. Functional analysis of NIF-1, a developmentally regulated Drosophila transcription factor that binds neuronal cis-elements. Genes \& Dev. 3: 1677-1688.

Eveleth, D.D. and J.L. Marsh. 1986. Evidence for evolutionary duplication of genes in the dopa decarboxylase region of Drosophila. Genetics 114: 469-483.

Fischer, S. and L. Lerman. 1983. DNA fragments differing in single base-pair substitutions are separated in denaturing gradient gels: Correspondence with melting theory. Proc. Natl. Acad. Sci. 80: 1579-1583.

Gergen, J.P. and E.F. Wieschaus. 1985. The localized requirements for a gene affecting segmentation in Drosophila: Analysis of larvae mosaic for runt. Dev. Biol. 109: 321-335.

Glaser, R.L., M.F. Wolfner, and J.T. Lis. 1986. Spatial and temporal pattern of $h s p 26$ expression during normal develop- 
ment. $E M B O$ /. 5: 747-754.

Gray, M., A. Charpentier, K. Walsh, P. Wu, and W. Bender. 1991. Mapping point mutations in the Drosophila rosy locus using denaturing gradient gel blots. Genetics 127: 139-149.

Hama, C., Z. Ali, and T.B. Kornberg. 1990. Region-specific recombination and expression are directed by portions of the Drosophila engrailed promoter. Genes \& Dev. 4: 1079 1093.

Ingham, P.W. 1988. The molecular genetics of embryonic pattern formation in Drosophila. Nature 335: 25-33.

Jiang, J., T. Hooey, and M. Levine. 1991. Autoregulation of a segmentation gene in Drosophila: Combinatorial interaction of even-skipped homeo box protein with a distal enhancer element. Genes \& Dev. 5: 265-275.

Johnson, W.A., C.A. McCormick, S.J. Bray, and J. Hirsh. 1989. A neuronal specific enhancer of the Drosophila dopa decarboxylase gene. Genes \& Dev. 3: 676-686.

Kassis J.A., C. Desplan, D.K. Wright, and P.H. O'Farrell. 1989. Evolutionary conservation of homeodomain binding sites and other sequences upstream and within the major transcription unit of the Drosophila segmentation gene engrailed. Mol. Cell. Biol. 9: 4304-4311.

Lewis, E.B. and F. Bachar. 1968. Method for feeding ethylmethanesulfonate (EMS) to Drosophila males. Drosophila Inf. Serv. 43: 193.

Lindsley, D.L. and E.H. Grell. 1968. Genetic variations of Drosophila melanogaster. Carnegie Inst. Washington Publ. 627.

Lindsley, D.L. and G. Zimm. 1985. The genome of Drosophila melanogaster: Part I. Drosophila Inf. Serv. 62.

-1990. The genome of Drosophila melanogaster: Part 4. Drosophila Inf. Serv. 68.

Livingstone, M.S. and B.L. Tempel. 1983. Genetic dissection of monoamine neurotrasmitter synthesis in Drosophila. $\mathrm{Na}$ ture 303: 67-70.

Nüsslein-Volhard, C., E. Wieschaus, and H. Kluding. 1984. Mutations affecting the pattern of the larval cuticle in Drosophila melanogaster. I. Zygotic loci on the second chromosome. Wilhelm Roux's Arch. Dev. Biol. 193: 267-282.

Pierani, A., A. Heguy, H. Fujii, and R.G. Roeder. 1990. The activation of octamer-containing promoters by either octamer binding transcription factor I (OTF-I) or OTF-2 and requirment of an additional B-cell-specific component for optimal transcription of immunoglobulin promoters. Mol. Cell. Biol. 10: 6204-6215.

Poellinger, L. and R.G. Roeder. 1989. Octamer transcription factors 1 and 2 each bind to two different functional elements in the immunoglobulin heavy chain promoter. Mol. Cell Biol. 9: 747-756.

Regulski, M., S. Dessain, N. McGinnis, and W. McGinnis. 1991. High affinity binding sites for the Deformed protein are required for the function of an autoregulatory enhancer of the Deformed gene. Genes \& Dev. 5: 278-286.

Reynolds, E.R. and J.M. O'Donnell. 1987. An analysis of the embryonic defects in Punch mutants of Drosophila melanogaster. Dev. Biol. 123: 430-441.

Sambrook, J., E.F. Fritsch, and T. Maniatis. 1989. Molecular cloning: A laboratory manual, 2nd ed. Cold Spring Harbor Laboratory Press, Cold Spring Harbor, New York.

Scholnick, S., S.J. Bray, B.A. Morgan, C.A. McCormick, and J. Hirsh. 1986. CNS and hypodermal regulatory elements of the Drosophila melanogaster dopa decarboxylase gene. Science 234: 998-1002.

Scott, M.P. and S.B. Carroll. 1987. The segmentation and homeotic gene network in early Drosophila development. Cell 51: 689-698.
Simon, J.A., C.A. Sutton, R.B. Lobell, R.L. Glaser, and J.T. Lis. 1985. Determinants of heat shock-induced chromosome puffing. Cell 40: 805-817.

Smolik-Utlaut, S.M. and W.M. Gelbart. 1987. The effects of chromosomal rearrangements on the zeste-white interaction in Drosophila melanogaster. Genetics 116: 285-298.

Soeller, W.C., S.J. Poole, and T. Kornberg. 1988. In vitro transcription of the Drosophila engrailed gene. Genes \& Dev. 2: $68-81$.

Stanojevic, D., T. Hoey, and M. Levine. 1989. Sequence specific DNA-binding activities of the gap proteins encoded by hunchback and Krüppel in Drosophila. Nature 341: 331335.

Tabor, S. and C.C. Richardson. 1987. DNA sequence analysis with modified bacteriophage T7 DNA polymerase. Proc. Natl. Acad. Sci. 84: 4767-4771.

Topol, J., B.M. Ruder, and C.S. Parker. 1985. Sequences required for in vitro transcriptional activation of a Drosophila hsp 70 gene. Cell 42: 527-537.

Valles, A.M. and K. White. 1986. Development of serotonin containing neurons in Drosophila mutants unable to synthesize serotonin. J. Neurosci. 6: 1482-1491.

Wieschaus, E. and C. Nüsslein-Volhard. 1986. "Looking at embryos" In Drosophila: A practical approach led D.B. Roberts), pp. 199-226. IRL Press, Oxford.

White, R.A.H. and M. Wilcox. 1984. Protein products of the bithorax complex in Drosophila. Cell 39: 163-171.

Wright, T.R.F. 1987. The genetics of biogenic amine metabolism, sclerotinization, and melanization in Drosophila melanogaster. Adv. Genet. 4: 127-222.

Wright, T.R.F., G.C. Bewley, and A.F. Sherald. 1976. The genetics of dopa decarboxylase in Drosophila melanogaster. II. Isolation and characterization of dopa decarboxylase deficient mutants and their relationship to the alpha-methyldopa hypersensitive mutants. Genetics 84: 287-310. 


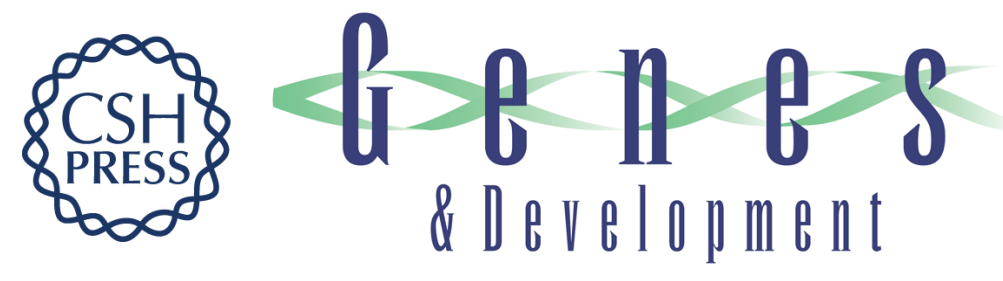

\section{Developmental function of Elf-1: an essential transcription factor during embryogenesis in Drosophila.}

S J Bray and F C Kafatos

Genes Dev. 1991, 5:

Access the most recent version at doi:10.1101/gad.5.9.1672

References This article cites 39 articles, 22 of which can be accessed free at: http://genesdev.cshlp.org/content/5/9/1672.full.html\#ref-list-1

License

Email Alerting

Receive free email alerts when new articles cite this article - sign up in the box at the top Service right corner of the article or click here.

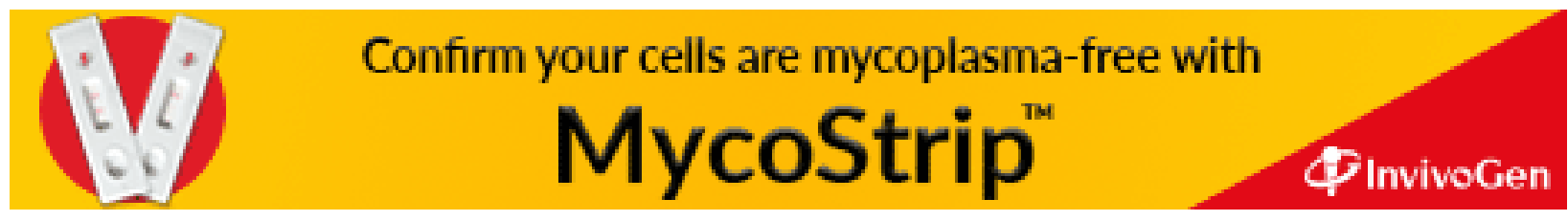

